\title{
Fatty Acid-Binding Protein, Adipocyte
}

National Cancer Institute

\section{Source}

National Cancer Institute. Fatty Acid-Binding Protein, Adipocyte. NCI Thesaurus. Code C29617.

Fatty acid-binding protein, adipocyte (132 aa, $15 \mathrm{kDa})$ is encoded by the human FABP4 gene. This protein is involved in binding to both long chain fatty acids and retinoic acid. 